\title{
Experimental Vibrio harveyi infections in Penaeus vannamei larvae
}

\author{
P. A. W. Robertson ${ }^{1}$, J. Calderon ${ }^{2}$, L. Carrera ${ }^{2, *}$, J. R. Stark $^{1}$, M. Zherdmant ${ }^{2}$, B. Austin ${ }^{1, * *}$ \\ ${ }^{1}$ Heriot-Watt University, Riccarton, Edinburgh EH14 4AS, Scotland, UK \\ ${ }^{2}$ Centro Nacional de Acuicultura e Investigaciones Marinas, Campus Politécnico, PO Box 09-01-4519, Guayaquil, Ecuador
}

\begin{abstract}
A culture of Vibrio harveyi, isolated from diseased Penaeus vannamej, was pathogenic in penaeid shrimp larvae when used in a bath at $10^{5}$ cells $\mathrm{ml}^{-1}$ for $2 \mathrm{~h}$. The resultant disease had characteristics of Bolitas negricans, as observed in Ecuadorian hatcheries, namely the development of bioluminescence, reduced feeding and retarded development, sluggish swimming, reduced escape mechanisms, degeneration of hepatopancreatic tissue with resultant formation of necrotic bundles, and increased mortality. Koch's Postulates were confirmed by reisolation and identification of the organism. Histopathology showed the presence of distinctive melanotic tissue aggregates within the hepatopancreas, with immunohistochemistry confirming the presence of large numbers of $V$. harveyi in the intestine and hepatopancreas. These results indicate a suitable infection protocol, which can be used to test the pathogenicity of putative pathogens of penaeid shrimp larvae.
\end{abstract}

KEY WORDS: Vibrio harveyi Penaeus vannamei larvae . Pathogenicity

Large-scale losses of larval and juvenile penaeids have been associated with epizootics of Vibrio sp. (Lightner et al. 1992, de la Peña et al. 1993, Song et al. 1993, Xu et al. 1993, Hameed \& Rao 1994, Lee et al. 1996). In particular, disease outbreaks attributed to luminous $V$. harveyi have been observed in the Philippines (Lavilla-Pitogo et al. 1990), Indonesia (Sunaryanto et al. 1986), Thailand (Jiravanichpaisal et al. 1994), India (Karunasagar et al. 1994), Australia (Pizzutto \& Hirst 1995) and Taiwan (Liu et al. 1996). In Ecuador, $V$. harveyi has been implicated with mass mortalities of Penaeus vannamei larvae, in the disease condition referred to as Bolitas negricans. The condition is characterised by a distinctive pathology of the hepatopancreas, where the tissue degenerates, form-

\footnotetext{
- Deceased

*Addressee for correspondence. E-mail: b.austin@hw.ac.uk
}

ing balls which eventually move into the upper gut. At the same time, larvae become bioluminescent, with accompanying behavioural changes and lack of appetite. Fortunately, the disease has been successfully controlled with antibiotics, although antibiotic resistant strains of $V$. harveyi have been recorded (Karunasagar et al. 1994).

It is often difficult to prove pathogenicity of bacterial isolates in penaeids because of the absence of suitable experimental models. Consequently, the aim of this study was to develop a system which would mimic the disease Bolitas negricans. Thus, Vibrio harveyi was evaluated for pathogenicity in Penaeus vannamei larvae.

Materials and methods. Penaeus vannamei larvae: $P$. vannamei larvae (nauplii VI and protozoea I/II), reared from specific pathogen-free broodstock (Wyban et al. 1993) imported from Hawaii, were obtained from a commercial hatchery (El Rosario S.A., Division Laboratorios) in Ecuador. P. vannamei protozoea $I$, in groups of 400 , were maintained in 21 volumes of aerated hatchery water in $5 \mathrm{l}$ capacity glass bottles. The experimental systems were maintained in a water bath thermostatically controlled at $28^{\circ} \mathrm{C}$. The larvae were acclimatised for $24 \mathrm{~h}$ prior to use in order to ensure adequate health. Daily feeding was with 100000 Chaetoceros sp. cells $\mathrm{ml}^{-1}$.

Bacterial culture: Vibrio harveyi STD3-101, which was isolated in Ecuador during 1994 from larvae showing clinical symptoms of Bolitas negricans, was used in the infectivity experiments. Authenticity of the isolate was verified after Baumann et al. (1984). Long-term storage was at $-70^{\circ} \mathrm{C}$. Working cultures were maintained on marine $2216 \mathrm{E}$ agar (MA; Difco), with subculturing every 1 to $2 \mathrm{wk}$. In subsequent experiments, the isolate was grown in a shaking water bath for $8 \mathrm{~h}$ at $28^{\circ} \mathrm{C}$ in a $1: 10$ dilution of lactose broth $[1 \%(\mathrm{w} / \mathrm{v})$ peptone, $0.5 \%(\mathrm{w} / \mathrm{v})$ yeast extract; $\mathrm{pH} 7.2$ ] supple- 
mented with $\mathrm{NaCl}$ to $2.5 \%(\mathrm{w} / \mathrm{v})$. The bacterial numbers were estimated using an improved Neubauer type haemocytometer at a magnification of $\times 400$. Viablc counts were recorded from the number of colonies resulting from spreading $0.1 \mathrm{ml}$ volumes onto triplicate plates of $\mathrm{MA}$ with incubation at $28^{\circ} \mathrm{C}$ for $48 \mathrm{~h}$.

Experimental infection of Penaeus vannamei larvae: Preliminary experiments showed that $P$. vannamei became infected within $2 \mathrm{~h}$ of immersion in bacterial suspensions. Longer periods led to multiplication of the - bacteria and extremely high and rapid mortalities. As a result of these preliminary, reproducible experimental infections of $P$. vannamei, larvae were infected by exposure for $2 \mathrm{~h}$ to between $10^{4}$ and $10^{7}$ bacterial cells $\mathrm{ml}^{-1}$. Then, the infected water was replaced with fresh ultraviolet-treated seawater. Appropriate controls were established, with water changes only.

The shrimp larvae were examined daily for $10 \mathrm{~d}$ for evidence of bioluminescence, changes in behaviour and in feeding patterns, differences in rates of development and mortality. Samples were taken throughout, with 20 individuals removed from each experimental system, then transferred to flamed microscope slides for examination by light microscopy $(\times 400)$. In particular, the hepatopancreas was observed for colour and turgidity, and the presence of any abnormalities. The general condition of the penaeids was assessed by observing the filling of the gut, and the presence of faecal strands. The stages of the larvae were recorded after Kitani (1986).

Microbiological examination: Groups of 10 larvae from all stocks, the Chaetoceros sp. used as food, and water from the experimental system were examined for the presence of Vibrio harveyi, prior to use. During the infectivity experiments, groups of 20 larvae were examined microbiologically. For this, the larvae and microalgae were transferred separately to sterile Eppendorf tubes, washed in $0.5 \mathrm{ml}$ volumes of sterile $0.85 \%(\mathrm{w} / \mathrm{v})$ saline, and homogenised in fresh saline. Dilutions (to $10^{-6}$ ) of the homogenates and water from the experimental system were prepared in fresh saline, and $0.1 \mathrm{ml}$ volumes were spread over the surface of triplicate thiosulphate citrate bile salts sucrose agar (TCBS, Oxoid) plates with incubation for $24 \mathrm{~h}$ at $28^{\circ} \mathrm{C}$. Bacterial cultures, which were luminescent and considered to resemble $V$. harveyi, were identified by examination of phenotypic characteristics (Baumann et al. 1984) and by immunoassay,

Immunoassay by dot and colony blot: A monoclonal antibody to Vibrio harveyi strain STD3-72, which had been obtained from diseased Penaeus vannamei larvae during an outbreak of Bolitas negricans in Ecuador (French et al. 1986), was used. Dot and colony blots were carried out, using appropriate positive and negative controls, by a modified method of Noel et al.
(1996). The colony blots were prepared by placing $0.45 \mu \mathrm{m}$ nitrocellulose filters (Millipore) onto TCBS agar plates, which had been inoculated with the culture and incubated for $8 \mathrm{~h}$ at $28^{\circ} \mathrm{C}$. After $10 \mathrm{~min}$, the filters were removed using flamed forceps, transferred to Petri dishes and left for 30 min to dry. Dot blots were prepared by emulsifying single colonies in $0.5 \mathrm{ml}$ volumes of phosphate buffered saline ( $\mathrm{PBS}_{\mathrm{p}} \mathrm{pH}$ 7.2). Volumes $(1 \mu l)$ of the bacterial suspensions were spotted onto nitrocellulose filters, which were air-dried for $30 \mathrm{~min}$.

The filters were incubated in PBS $+5 \%(\mathrm{w} / \mathrm{v})$ skimmed milk (Oxoid) for $45 \mathrm{~min}$ to block all the unbound sites. After washing twice, each for $3 \mathrm{~min}$, with PBS $+1 \%(\mathrm{v} / \mathrm{v})$ Tween 20 (Sigma), the filters were incubated for $45 \mathrm{~min}$ with a 1:3000 dilution in PBS + $0.5 \%$ (w/v) skimmed milk of the monoclonal antibody. The filters were re-washed, as before, then incubated for 45 min with a 1:15000 dilution of donkey antimouse immunglobulin IgG conjugated with alkaline phosphatase (Sigma) in PBS $+0.5 \%(\mathrm{w} / \mathrm{v})$ skimmed milk. After further washing, the filters were incubated in the dark for $20 \mathrm{~min}$ with bromo-4-chloro-3-indolylphosphate/nitroblue tetrazolium (Sigma) in Tris buffer (0.5 $\mathrm{mM} \mathrm{MgCl}_{2}$ ) at $\mathrm{pH} 10.0$. The reaction was stopped by washing in PBS $+2 \mathrm{mM}$ of EDTA. Positive reactions resulted in the formation of an intense blue colour, whereas negatives remained colourless.

Histopathology and immunohistochemistry: Diseased larvae, in groups of 10, were fixed in Davidson's fixative for $6 \mathrm{~h}$ (note: greater periods led to deterioration of the larvae), transferred to $70 \%$ ethanol until required and then processed in mesh bags (Life Sciences International). The paraffin wax embedded larvae were sectioned, mounted on poly-L-lysine (Sigma) coated slides, and stained with Harris' haematoxylin and eosin (Bucke 1989) or used for immunohistochemistry. For this, an immunoassay was developed using polyclonal antibodies produced in a female New Zealand white rabbit to Vibrio harveyi STD3-101 (titre by whole cell agglutination $\geq 1: 8192$ ). The tissue sections were incubated for $30 \mathrm{~min}$ at $22^{\circ} \mathrm{C}$ with $5 \%$ $(\mathrm{v} / \mathrm{v})$ sheep serum [Scottish Antibody Production Unit (SAPU), Carluke, Scotland] in PBS. After washing 3 times for 5 min with PBS, the sections were incubated for $1 \mathrm{~h}$ with a $1: 2000$ dilution in PBS $+0.5 \%(\mathrm{v} / \mathrm{v})$ sheep serum (SAPU) of the polyclonal antibody to $V$. harveyi. The sections were re-washed thrice for $5 \mathrm{~min}$ in PBS, before incubation for $1 \mathrm{~h}$ with a 1:250 dilution in PBS + $0.5 \%(\mathrm{v} / \mathrm{v})$ sheep serum of goat anti-rabbit IgG conjugated with alkaline phosphatase (Sigma). After further washing, $1 \mathrm{mg} \mathrm{ml}^{-1}$ of Fast Red ( $\alpha$-naphthol; Sigma) was added for $10 \mathrm{~min}$. The reaction was monitored to avoid overdevelopment of the stained tissues, and stopped by incubation with PBS +2 mM EDTA. The 
sections were counterstained with haematoxylin (Bucke 1989), dehydrated, and mounted in a xylene substitute mountant (Life Sciences International). Positivity was indicated by the presence of a pink coloration, which contrasted well with the natural pigmentation of the tissues.

Results and discussion. At the onset of the pathogenicity experiment, Vibrio harveyi was not detected in larvae, algae or water samples. Furthermore, throughout the duration of the experiment, $V$. harveyi was not detected in any of the uninfected larvae (Table 1). Control individuals developed normally, and by the time of mysis (Day 4), they were extremely active and difficult to catch. Conversely, larvae which were infected with an inoculum of $10^{7}$ cells took longer to reach mysis stages (MI/II; Day 8), were sluggish, swam near the bottom of the tank, and were easily caught. Larvae infected with $10^{5}$ and $10^{6}$ cells $\mathrm{ml}^{-1}$ displayed similar signs, although less pronounced, whilst those challenged with $10^{4}$ cells $\mathrm{ml}^{-1}$ showed no differences to the controls. $V$. harveyi was detected in all infected larvae, even those which lacked pronounced pathology. Bioluminescence was observed up to Day 6 in larvae infected with $>10^{5}$ cells $\mathrm{ml}^{-1}$ (Table 2). Clinical signs of Bolitas negricans were most evident at $2 \mathrm{~d}$ post-infection in shrimp larvae infected with $10^{5}$ to $10^{7}$ cells $\mathrm{ml}^{-1}$, although pathology was still observed to the end of the experiment. Larvae infected with $10^{4}$ cells $\mathrm{ml}^{-1}$ also showed pathology, although less chronic and only in the first $2 \mathrm{~d}$ after infection. The highest mortalities were recorded during the change from protozoea III to mysis I. By the end of the experiment, survival in larvae infected with $10^{4}, 10^{5}, 10^{6}$ and $10^{7}$ cells $\mathrm{ml}^{-1}$ was $90,53,81$ and $51 \%$, respectively. Mortalities were not recorded among the controls.

The hepatopancreas of control larvae maintained a good shape and colour and the guts were filled with food. In early, or acutely, infected individuals changes were seen in the internal structure of the hepatopancreas. In particular, the organ was less turgid, and

Table 1. Presence of Vibrio harveyi in Penaeus vannamei larvae, as determined by colony and dot blots after infection by immersion. ' +++ ', ' $+t$ ', ' + ' and ' - ' correspond to dense, moderate, low and no growth of $V$. harveyi, respectively

\begin{tabular}{|lcccccccc|}
\hline & \multicolumn{8}{c|}{ No. of days after infection } \\
Infectivity dose & (no. of bacteria $\left.\mathrm{ml}^{-1}\right)$ & 1 & 2 & 3 & 4 & 6 & 8 & 10 \\
\hline 0 & - & - & - & - & - & - & - \\
$10^{4}$ & ++ & ++ & + & + & + & + & + \\
$10^{5}$ & +++ & +++ & +++ & ++ & ++ & ++ & ++ \\
$10^{6}$ & +++ & +++ & +++ & ++ & ++ & ++ & ++ \\
$10^{7}$ & +++ & +++ & +++ & ++ & ++ & ++ & ++ \\
\hline
\end{tabular}

Table 2. Vibrio harveyi infecting Penaeus vannamei. Number of larvae exhibiting bioluminescence

\begin{tabular}{|lcccccccc|}
\hline $\begin{array}{l}\text { Infectivity dose } \\
\text { (no. of bacteria } \mathrm{ml}^{-1} \text { ) }\end{array}$ & 1 & 2 & 3 & 4 & 6 & 8 & 10 \\
\hline $0-10^{4}$ & - & - & - & - & - & - & - \\
$10^{5}$ & - & 2 & - & - & - & - & - \\
$10^{6}$ & 4 & 3 & 3 & 2 & 1 & - & - \\
$10^{7}$ & 6 & 3 & 2 & 5 & 1 & - & - \\
\hline
\end{tabular}

bundles of tissue were beginning to form. The hepatopancreas of chronically infected larvae were grey and emaciated, with balls of necrotic tissue (from the hepatopancreas) blocking the upper gut. Apparently, the larvae were unable to ingest, and the gut was totally devoid of food. At this stage, the larvae were close to death.

Examination of fixed tissues from healthy larvae showed structural integrity within the hepatopancreas and gut (Fig. 1). In comparison, infected protozoea III, which were exhibiting classical signs of Bolitas negricans, had a distinctive pathology, characterised by the formation of bundles of necrotic tissue within the hepatopancreas (Fig. 2). Where necrotic bundles had formed, the emaciated walls of the hepatopancreas were particularly evident.

By immunohistochemistry, Penaeus vannamei larvae infected by immersion with $10^{5}$ to $10^{7}$ cells $\mathrm{ml}^{-1}$ revealed the presence of Vibrio harveyi in large numbers in the upper areas of the gut. Positive staining was also observed within hepatopancreas tubules, indicating a degree of colonisation in that area. There was no evidence for the presence of bacteria associated directly within necrotic bundles in the hepatopancreas. Uninfected tissues, serving as controls, were uniformly negative.

Changes in environmental conditions are capable of retarding and enhancing the virulence of Vibrio harveyi (Prayitno et al. 1995). Therefore, when attempting to assess the potential to elicit disease, it is necessary to be careful about the storage and culture of the isolate, because of the subsequent effect this may have on pathogenicity. From the experiments undertaken here, Koch's Postulates were fulfilled, insofar as after causing disease signs in larvae, the bacteria were reisolated in pure culture and identified as $V$. harveyi. Furthermore, disease symptoms associated with Bolitas negricans were seen only in larvae infected with $V$. harveyi, whereas controls remained healthy throughout the experiments. A distinctive histopathology was observed, and correlated with the presence of $V$. harveyi in infected larvae, as elucidated by immunohistochemistry. Indeed, following the course of infection, a range of severities, with highest doses of 
Fig. 1. Penaeus vannamei. Healthy hepatopancreas and gut in control larvae. Scale bar $=0.5 \mathrm{~mm}$.

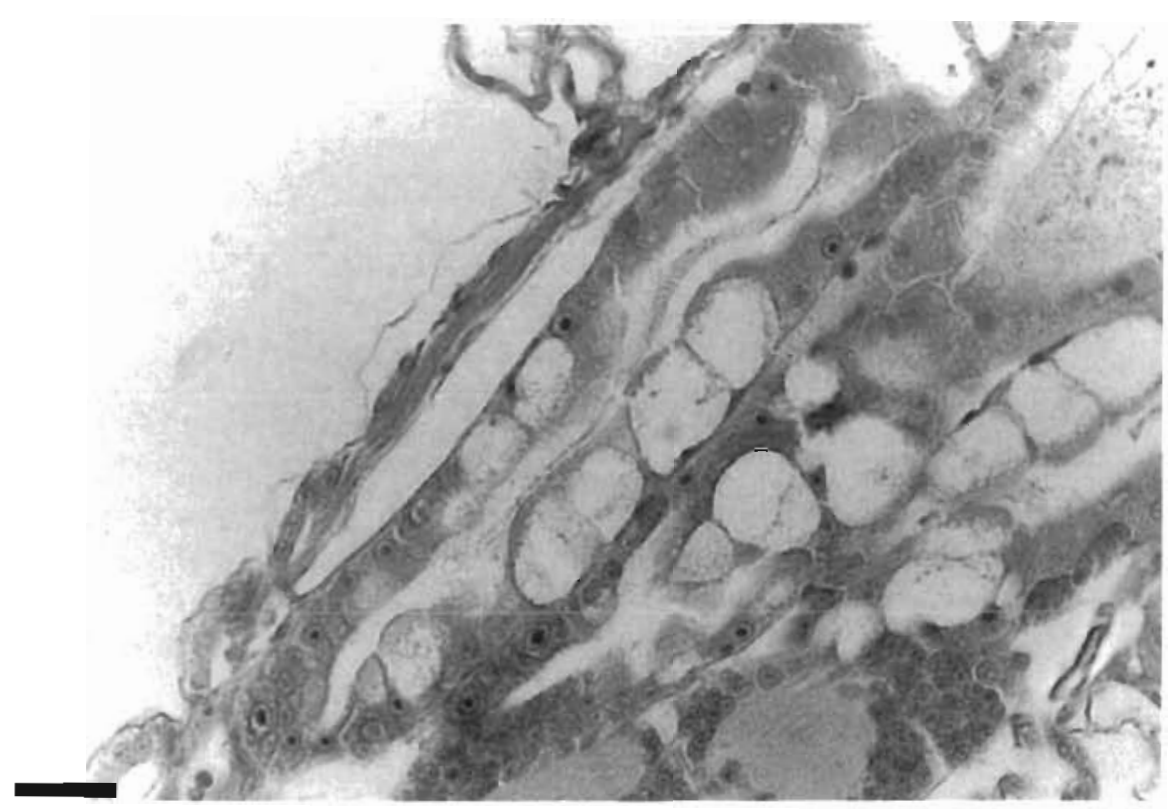

bacteria producing the most clear pathology, was observed. The low level of mortality recorded in infected individuals was probably attributable to the previous good health status of the larvae, as evident from a lack of mortality in controls.

It was clear that, at the end of the study, although no sudden mortality was observed, survivors were still exhibiting pathology and behavioural changes, indicative of damage to the digestive system. Coincidentally, a similar situation sometimes occurs in Ecuadorian hatcheries, where Bolitas negricans affected larvae appear to recover, but then slowly die off before reaching later post-larval stages.

In conclusion, a reproducible infection model has been described, which is suitable for assessing pathogenicity in penaeid shrimp larvae. In this study, disease resembling the condition Bolitas negnicans was elicited, solely arising from an artificial infection of Vibrio harveyi

Acknowledgements. Financial support was provided by EUSTD contract number TS3-CT94-0269. We thank D. Garriques for the supply of larvae.

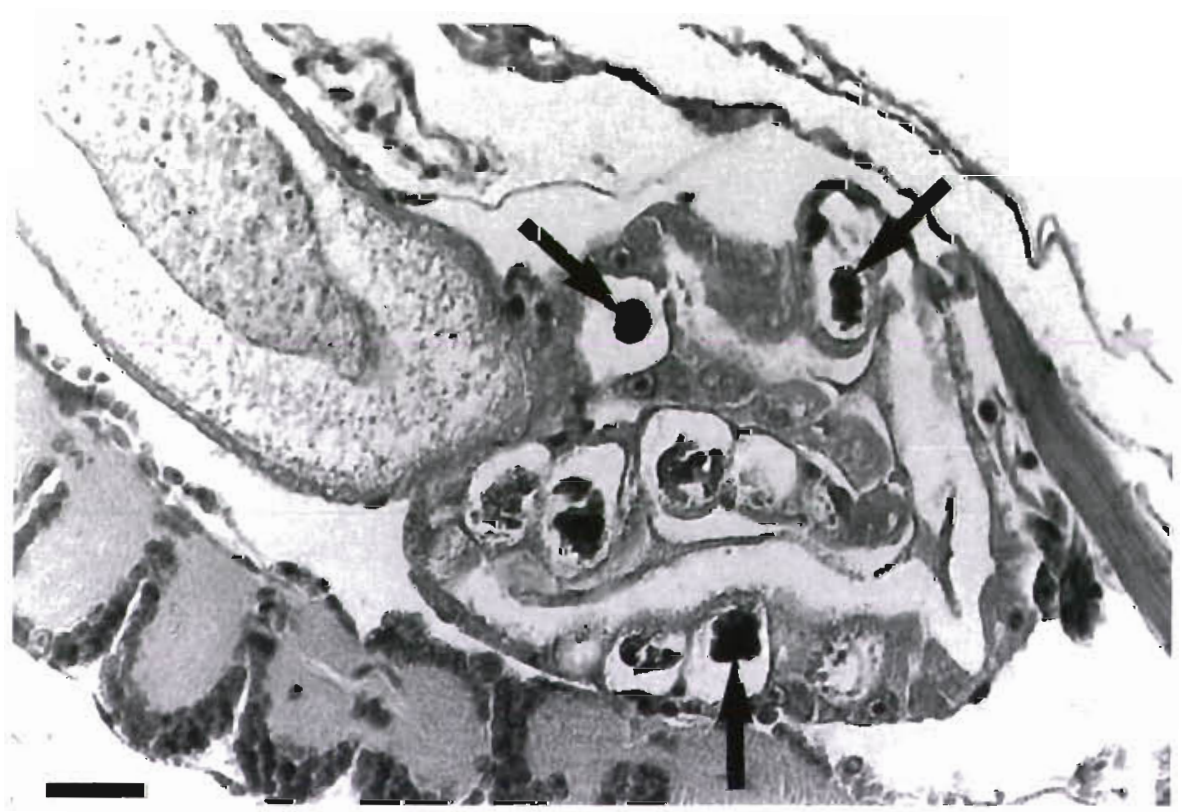

Fig. 2. Penaeus vannamei infected with Vibrio harveyi. Chronically diseased hepatopancreas showing melanised necrotic bundles of tissue. Arrows indicate necrotic aggregates within the hepatopancreas. Scale bar $=0.5 \mathrm{~mm}$ 


\section{LITERATURE CITED}

Baumann P, Furniss AL, Lee JV (1984) Genus 1 Vibrio Pacini 1854, 411 AL In: Krieg NR, Holt JG (eds) Borgey's manual of systematic bacteriology, Vol 1 Willams and Wilkins, Baltimore, p 518-538

Bucke D (1989) Chap 5. Histology. In: Austin B, Austun DA (eds) Methods for the microbiological examination of fish and shellfish. Ellis Horwood, Chichester, p 69-97

French D, Fischberg E, Buhl S, Shariff MD (1986) The production of more useful monoclonal antibodies. I. Modifications of the basic technology. Immunol Today 7:344-346

Hameed ASS, Rao PV (1994) Studies on the chemical contro] of a Vibrio campbellii-like bacterium affecting hatcheryreared Penaeus indicus larvae. Aquaculture 127:1-9

Jiravanichpaisal P, Miyazaki T, Limsuwan C (1994) Histopathology, biochemistry, and pathogenicity of Vibrio harveyi infecting black tiger prawn Penaeus monodon. $\mathrm{J}$ Aquat Anim Health 6:27-35

Karunasagar I, Pai R, Malathi GR, Karunasagar I (1994) Mass mortality of Penaeus monodon larvae due to antibiotic resistant Vibrio harveyi infection. Aquaculture 128 : 203-209

Kitani H (1986) Larval development of the white shrimp Penaeus vannamei Boone reared in the laboratory and the statistical observation of its naupliar stages. Bull Jpn Soc Sci Fish 52:1131-1139

Lavilla-Pitogo CR, Baticados MCL, Cruz-Lacierda ER, de la Peña LD (1990) Occurrence of luminous bacterial disease of Penaeus monodon larvae in the Philippines. Aquaculture 91:1-13

Lee KK, Yu SR, Yang TI, Liu PC, Chen FR (1996) Isolation and characterisation of Vibrio alginolyticus isolated from diseased kuruma prawn, Penaeus japonicus. Lett Appl Microbiol 22:111-114

Lightner DV, Bell TA, Redman RM, Mohney LL, Natividad JM, Rukyani A, Poernomo A (1992) A review of some

Editorial responsibility: David Bruno,

Aberdeen, Scotland, UK major diseases of economic significance in penaeid prawns/shrimp of the Americas and Indopacific. In: Shariff M. Subasinghe RP, Arthur JR (eds) Diseases in Asian Aquaculture. 1 Asian Fisheries Society, Manila, p 57-80

Liu PC, Lee KK, Yii KC, Kou GH, Chen SN (1996) Isolation of Vibrio harveyi from diseased kuruma prawns Penaeus japonicus. Curr Microbiol 33:129-132

Noel T, Nicolas JL, Boulo V, Mialhe, E (1996) Development of a colony-blot ELISA assay using monoclonal antibodies to identify Vibrio P1 responsible for 'brown ring disease': in the clam Tapes philippinarum. Aquaculture 146:171-178

de la Peña LD, Tamaki T, Momoyama K, Nakai T, Muroga K (1993) Characteristics of the causative bacterium of vibriosis in the kuruma prawn, Penaeus japonicus. Aquaculture 115: $1-12$

Pizzutto M. Hirst RG (1995) Classification of isolates of Vibrio harveyi virulent to Penaeus monodon larvae by protein profile analysis and M13 DNA fingerprinting. Dis Aquat Org 21:61-68

Prayitno SB, Latchford JW (1995) Experimental infections of crustaceans with luminous bacteria related to Photobacterium and Vibrio. Effect of salinity and pH on infectiosity. Aquaculture 132:105-112

Song YL, Lee SP (1993) Characterisation and ecological implication of luminous Vibrio harveyi isolated from tiger shrimp (Penaeus monodon). Bull Inst Zool Acad Sin (Taipei) $32: 217-220$

Sunaryanto A, Mariam A (1986) Occurrence of a pathogenic bacteria causing luminescence in penaeid larvae in Indonesian hatcheries. Bull Brackishwater Aquacult Dev Cen 8:105-1.12

Wyban JA. Swingle JS, Sweeney JN, Pruder GD (1993) Specific pathogen free Penaeus vannamei. World Aquacult $24: 39-45$

Xu B, Xu HS, Ji W, Shj J (1993) Pathogens and pathogenicity to Penaeus orientalis Kishinouye. Acta Oceanol Sin 14 : $297-304$

Submitted: August 12, 1997; Accepted: November 17, 1997 Proofs received from author(s): February 16, 1998 